\title{
ELEVATED UNCONJUGATED BILIRUBIN IN SCHIZOPHRENIC PATIENTS
}

\author{
Ilhamuddin Azis ${ }^{1}$, Yuyun Widaningsih ${ }^{2}$, Rosdiana Natzir ${ }^{1}$, A. Jayalangkara Tanra ${ }^{3}$ \\ ${ }^{1}$ Department of Biochemistry, Faculty of Medicine, Hasanuddin University \\ ${ }^{2}$ Department of Clinical Pathology, F baculty of Medicine, Hasanuddin University \\ ${ }^{3}$ Department of Psychiatry, Faculty of Medicine, Hasanuddin University
}

Correspondence author:

\section{Ilhamuddin Azis}

Departement of Pathology Anatomy, Medical Faculty of Hasanuddin University

Email: ilo_kays@yahoo.com

\section{Article Info:}

Received: 04 August 2017

Revised: 25 April 2018

Accepted: 30 May 2018

Available online: 31 December 2018

Keywords: Unconjugated bilirubin, Gilbert's syndrome, psychoses, schizophrenia

DOI: $10.20956 / n m s j . v 3 i 1.5780$

\begin{abstract}
Introduction: Strategies for schizophrenic treatment are still under development in order to increase their effectively, based on latest findings in the etio-pathology. Coincidence of hyperbilirubinemia, especially related to Gilbert's Syndrome (GS), and schizophrenia/other psychiatric disorders, was reported in several studies although the pattern of this alteration is still controversial. Bilirubin could induce microglia to release pro-inflammatory cytokine that cause neuroinflammation, one of hypothetic etio-pathogenesis has been the most extensively studied recently. However, no data have been presented about this phenomenon in Indonesia. Therefore, this study aims to investigate plasma bilirubin concentration in psychotic spectrum.

Methods: This study is cross sectional design that examined both the total bilirubin and direct bilirubin of every psychotic patient admitted for the first time to Rumah Sakit Khusus Daerah (RSKD) Provinsi Sulawesi Selatan, by using health people as control. Diagnostic determination was set based on International Classification of Diseases (ICD) 10. Patients suffering from any disease such as anemia (decreased hemoglobin), liver diseases (elevated liver enzymes), or substance abuse were excluded.

Results: From 73 samples, we found that plasma UCB level was significantly elevated, higher in psychotic patients, especially schizophrenic group, than in the control. Total bilirubin rate was slightly increased in schizophrenic group compare to the others and two samples in this group showed hyperbilirubinemia.

Conclusion: Further investigations are needed to ensure that whether the elevated UCB was related to GS and whether this condition has inflammatory effect.
\end{abstract}




\section{Pendahuluan}

Gangguan jiwa psikotik masih menjadi salah satu problem kesehatan di Indonesia karena prevalensinya yang tinggi $( \pm 1.065 .000$ jiwa, data 2007). Gangguan yang umumnya terjadi pada usia produktif (15-45 tahun) ini mengakibatkan beban psiko-sosio-ekonomi bagi keluarga, masyarakat, dan negara. Beban ekonomi akibat gangguan jiwa lebih besar $(\operatorname{Rp} 20 \quad \mathrm{~T})$ dibandingkan dengan kerugian ekonomi dalam menangani kasus TBC (Rp6,2 T). ${ }^{1}$ Terapi yang lebih rasional dibutuhkan untuk mengurangi frekuensi kekambuhan, mempercepat waktu terapi, meningkatkan produktivitas dan kualitas hidup penderita, serta mencegah orang yang mempunyai kerentanan tinggi. Pendekatan dalam penatalaksanaan skizofrenia yang masih terus berkembang tentunya mesti didukung oleh discovery etio-patogenesis penyakit ini yang umumnya masih bersifat hipotetik.

Salah satu hipotesis yang berkembang saat ini adalah ditemukannya keterlibatan/peranan sistem imun, yaitu teori infeksi dan atau autoimun, neuroinflamasi, neurotoksik, degenerasi neuronal, ataupun penurunan neurogenesis. Akira Monji et al. (2011) menyatakan bahwa neuropatologi skizofrenia berkaitan erat dengan aktivasi mikroglia yang ditunjukkan dengan adanya efek inhibisi dari antipsikotik tipikal dan atipikal terhadap pelepasan sitokin inflamasi dan radikal bebas. ${ }^{2}$ Tanda inflamasi dan aktivasi mikroglia pada jaringan otak postmortem, disfungsi sawar darah otak, peningkatan aktivitas retroviral, dan lainnya merupakan indikator kuat adanya dasar imunologis etiopatologi skizofrenia (Karanikas EP, 2011). ${ }^{3}$ Salah satu penginduksi inflamasi otak yang dieksplorasi adalah bilirubin.

Hubungan peningkatan bilirubin dengan skizofrenia ataupun gangguan psikotik lainnya telah dilaporkan meskipun hasilnya tidak konsisten, berbeda di beberapa tempat. Peningkatan bilirubin ini (idiophatic unconjugated hyperbilirubinemia) juga dikaitkan dengan adanya penurunan aktivitas enzim glukuronil transferase akibat polimorfisme daerah promoter ataupun mutasi di beberapa titik pada gen UGT1A1 yang dikenal sebagai Gilbert's Syndrome (GS) dengan prevalensi sekitar 3-7\% populasi dunia. Telah dilaporkan bahwa sebagian pasien skizofrenia di Jepang mempunyai kadar bilirubin yang relatif lebih tinggi secara signifikan dibandingkan dengan gangguan psikiatrik lain dan kontrol/normal. (Miyaoka et al., 2000). ${ }^{4}$ Penelitian di Switzerland (Bach DR et al., 2010) yang justru menemukan hiperbilirubinemia pada gangguan psikotik akut dan sementara merekomendasikan dilakukannya penelitian tersebut dengan ikut menganalisis gen pengkode glukuronil transferase. ${ }^{5}$ Penelitian terkait hubungan hiperbilirubinemia dengan psikotik atau skizofrenia belum dilakukan pada pasien di Indonesia. Penelitian ini bertujuan mengetahui perbandingan kadar bilirubin pada berbagai spektrum psikotik.

\section{Metode}

Penelitian ini merupakan penelitian cross sectional atas pasien psikotik yang dirawat inap pertama kali di Rumah Sakit Khusus Daerah (RSKD) Provinsi Sulawesi Selatan selama periode Juli-Desember 2012. Pasien dengan komorbiditas penyakit fisik yang ditemukan pada pemeriksaan fisis dan laboratorium, khususnya anemia dan gangguan fungsi hati, serta penyalahgunaan NAPZA, dieksklusi dari subjek penelitian. Sampel darah dikoleksi dan dilakukan pemeriksaan kadar bilirubin total dan bilirubin direk. Subjek penelitian dibagi tiga kelompok, yaitu kelompok skizofrenia, psikotik nonskizofrenia, dan kontrol. Adapun diagnosis gangguan jiwa ditetapkan berdasarkan International Classification of Diseases (ICD) $10 .^{6}$

Data kadar bilirubin pasien dan kontrol diolah dengan menggunakan SPSS versi 19. Kadar bilirubin total dan UCB pada ketiga kelompok dianalisis dengan One-Way ANOVA, sedangkan analisis hubungan unconjugated hyperbilirubinemia dengan cut off rasio direct bilirubin/total bilirubin $<20-30 \%^{7}$ menggunakan chi-square. 


\section{Hasil}

Jumlah pasien yang memenuhi kriteria inklusi dan eksklusi dalam penelitian ini sebanyak 73 subjek dengan diagnosis skizofrenia 31 dan psikotik nonskizofrenia 32 (tabel). Berdasarkan ICD 10 (grafik 1), diagnosis terbanyak adalah skizofrenia ytt (28) dan gangguan psikotik non-organik ytt (28). Diagnosis lain yang didapatkan di antaranya adalah paranoid schizophrenia (1), acute and transient psychotic disorder (1), schizoaffective disorder (1), gangguan afektif bipolar, episode kini mania tanpa gejala psikotik (1), dan episode depresi berat dengan gejala psikotik (1). Umumnya subjek penelitian berumur 26-35 tahun (minimal 21, maksimal 45) dan proporsi laki-laki lebih banyak dengan $p$ value $=0.377$ dan 0.36 di antara tiga kelompok.
Secara umum, baik kelompok skizofrenia maupun psikotik non-skizofrenia menunjukkan kadar bilirubin total dan UCB dalam batas normal. Rata-rata bilirubin total untuk kelompok gangguan psikotik skizofrenia $=0,54 \pm 0.28$ $\mathrm{mg} / \mathrm{dL}$, sedangkan untuk kelompok nonskizofrenia $=0,46 \pm 0.19 \mathrm{mg} / \mathrm{dL}$ dan kontrol $=0.25 \pm 0.83 \mathrm{mg} / \mathrm{dL}$. Jumlah subjek yang kadar bilirubin totalnya $>1 \mathrm{mg} / \mathrm{dL}$ sebanyak 2 orang, berasal dari kelompok skizofrenia. Meskipun demikian, kadar bilirubin total di antara tiga kelompok mempunyai nilai perbedaan yang sedikit bermakna $p=0.003$. Perbedaan kadar UCB secara signifikan berbeda $(p=0.000)$, utamanya jika membandingkan kelompok skizofrenia dan kontrol ataupun kelompok psikotik nonskizofrenia dengan kontrol (tabel). Persentase UCB dalam darah pasien kelompok skizofrenia dan psikotik non-skizofenia nampak lebih tinggi dibandingkan kontrol (Grafik 2).

Tabel karakteristik sampel, perbandingan kadar bilirubin, dan $p$ value

\begin{tabular}{|c|c|c|c|c|}
\hline & $\begin{array}{l}\text { Spektrum } \\
\text { Skizofrenia }\end{array}$ & $\begin{array}{l}\text { Gangg. Psikotik } \\
\text { Non-skizofrenia }\end{array}$ & Normal/Kontrol & \\
\hline $\mathrm{n}$ & 31 & 32 & 10 & \\
\hline Umur (tahun) & $33.19 \pm 6.53$ & $31.75 \pm 5.69$ & $30.3 \pm 5.77$ & $p=0.377(\mathrm{ANOVA}$ \\
\hline $\begin{array}{l}\text { Jenis Kelamin } \\
(\% \text { male / \%female })\end{array}$ & $80.64 / 19.36$ & $93.75 / 6.25$ & $60 / 40$ & $\begin{array}{l}p=0.36 \\
\left(\chi^{2}, \text { Pearson }\right)\end{array}$ \\
\hline Bilirubin Total (mg/dL) & $0.54 \pm 0.28$ & $0.46 \pm 0.19$ & $0.25 \pm 0.83$ & $p=0.003$ \\
\hline Bilirubin Total > 1 & 2 & 0 & 0 & $\begin{array}{l}\text { (ANOVA) } \\
p=0.000\end{array}$ \\
\hline Unconj. Bil. (mg/dL) & $0.41 \pm 0.25$ & $0.31 \pm 0.16$ & $0.07 \pm 0.06$ & (ANOVA) \\
\hline \% Bil. Direk /Bil. Total & 25.97 & 34.01 & 50.53 & \\
\hline $\mathrm{BD} / \mathrm{BT}<20 \%$ & 11 & 0 & 0 & \\
\hline $\mathrm{BD} / \mathrm{BT}=20-30 \%$ & 12 & 14 & 0 & $\begin{array}{l}p=0.000 \\
\left(\chi^{2}, \text { Fisher's Exact }\right.\end{array}$ \\
\hline $\mathrm{BD} / \mathrm{BT}>30 \%$ & 8 & 18 & 10 & Test) \\
\hline
\end{tabular}


Grafik 1. Distribusi kelompok skizofrenia dan psikotik nonskizofrenia berdasarkan ICD 10

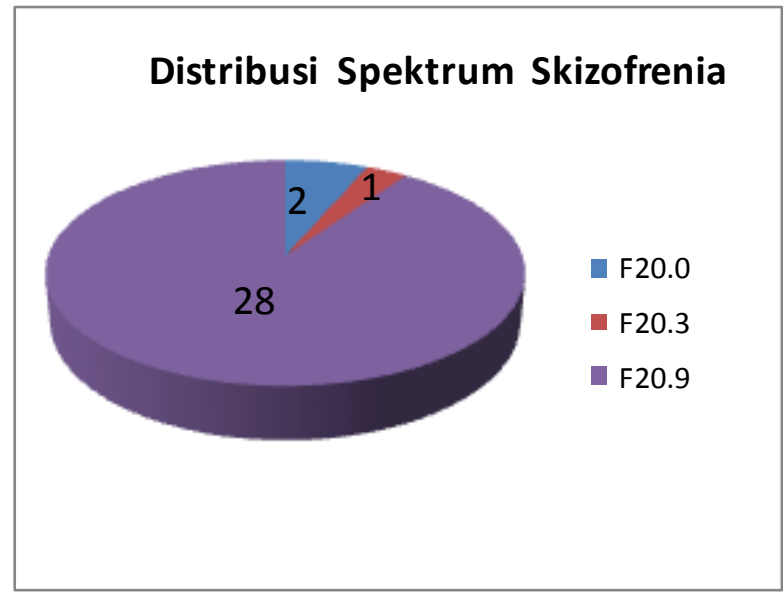

Kelompok skizofrenia yang memiliki perbandingan bilirubin direk/bilirubin total < $20 \% \quad$ (unconjugated hyperbilirubinemia) sebanyak $35.48 \%$ sampel, sedangkan pada kedua kelompok lainnya tidak ditemukan. Pada kontrol,

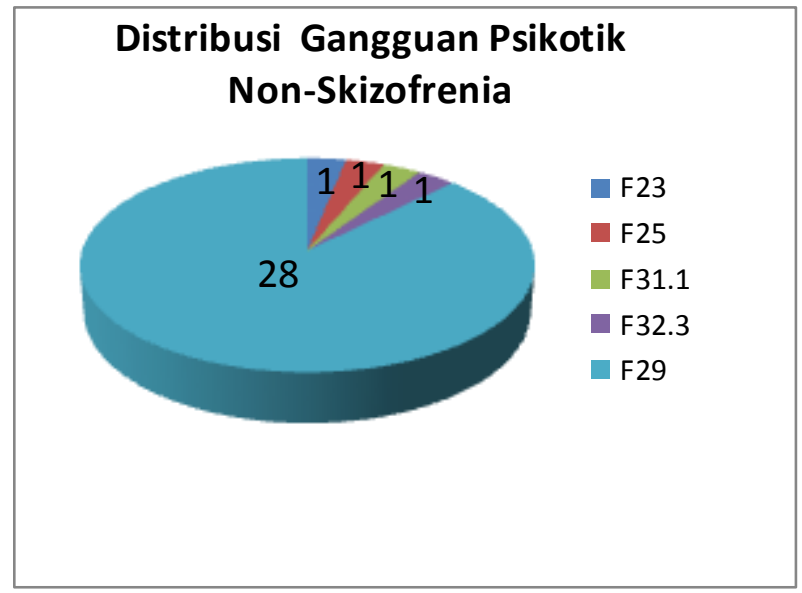

semua sampel menunjukkan rasio $\mathrm{DB} / \mathrm{TB}>30 \%$ (grafik 3). Secara statistik, perbedaan rasio DB/TB untuk ketiga kelompok menunjukkan $p$ value yang signifikan $(p=0.000)$.

Grafik 2. Perbandingan persentase unconjugated bilirubin dan conjugated bilirubin

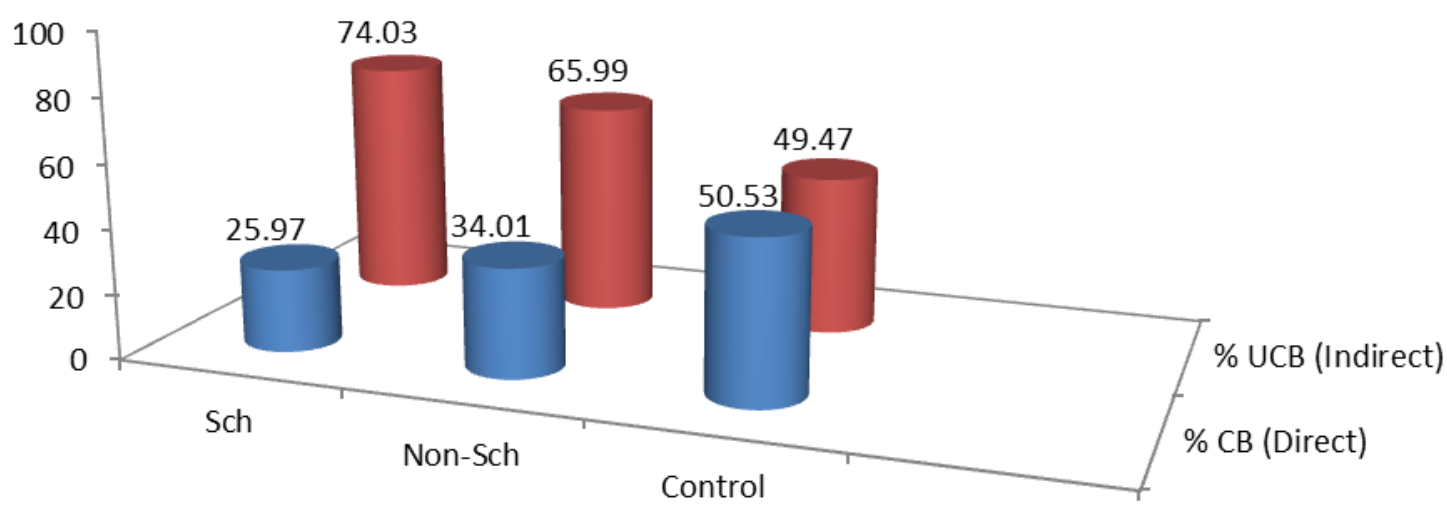


Gambar 3. Rasio bilirubin direk/bilirubin total dengan cut off $\mathbf{2 0 - 3 0 \%}$

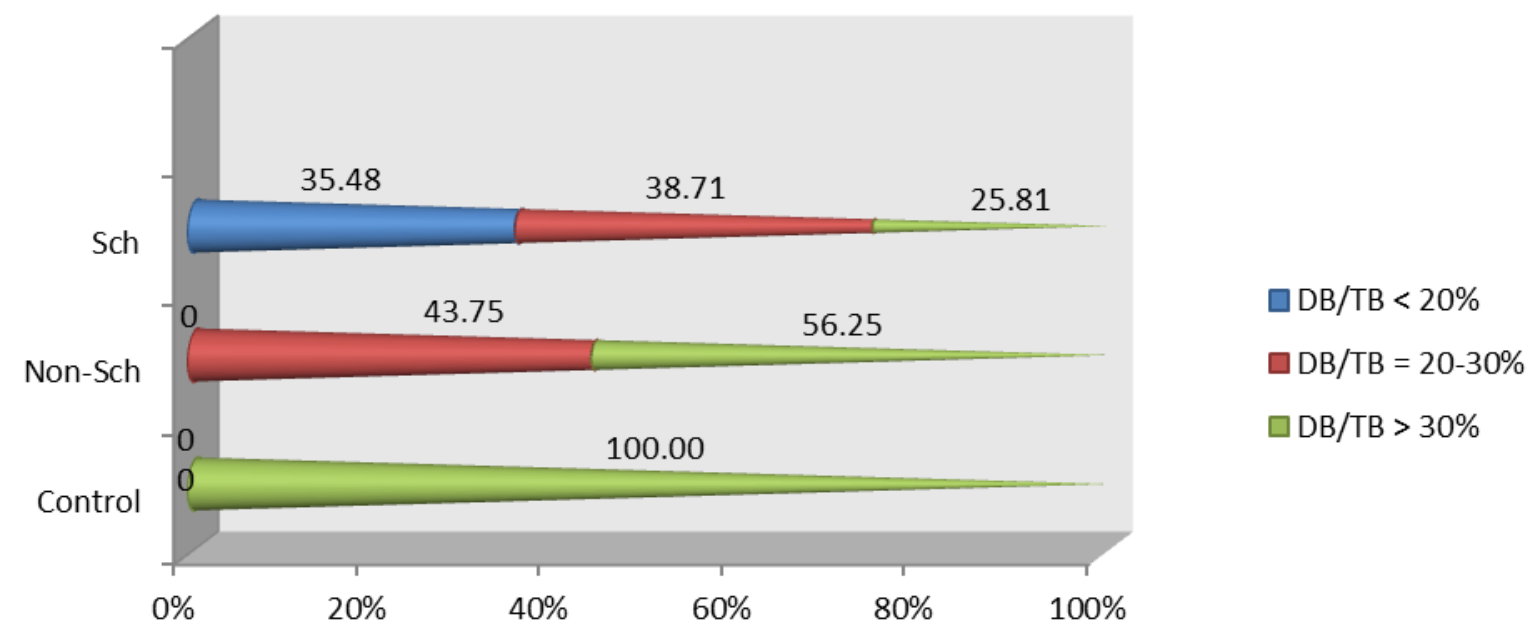

\section{Pembahasan}

Bilirubin yang merupakan produk sisa katabolisme hemoglobin telah lama dikenal sebagai marker pada gangguan darah, hati, dan empedu. Berbagai gangguan pada metabolisme bilirubin dapat menyebabkan peningkatan kadar bilirubin dalam darah (hiperbilirubinemia). Kondisi hiperbilirubinemia menjadi salah satu simptom pada berbagai penyakit. Selain sebagai marker, kadar bilirubin (unconjugated bilirubin) yang tinggi mempunyai efek toksik, utamanya pada jaringan otak. ${ }^{5}$ Efek unconjugated hyperbilirubinemia juga dikaitkan dengan gangguan psikiatri, khususnya psikotik ataupun skizofrenia.

Telah dilaporkan bahwa kelompok skizofrenia memiliki kadar bilirubin lebih tinggi dibandingkan kelompok bipolar disorder dan kontrol. Pada penelitian lain justru melaporkan peningkatan bilirubin tersebut terjadi pada gangguan psikotik akut dan sementara dibandingkan dengan jenis gangguan psikotik lainnya. Tingginya kadar bilirubin tersebut berhubungan dengan general symptom dibandingkan dengan simptom positif pada PANSS. Berbeda dengan hasil tersebut, temuan lain menunjukkan bahwa peningkatan bilirubin berkorelasi dengan general symptom dan positive symptom. ${ }^{4,5,8}$ Pada penelitian ini, meskipun kadar bilirubin umumnya masih dalam batas normal, kadar UCB relatif lebih tinggi pada pasien psikotik, utamanya yang didiagnosis sebagai skizofrenia, dibandingkan dengan kontrol.

Kadar UCB yang relatif lebih tinggi pada psikotik/skizofrenia dalam penelitian ini tidak ada hubungannya dengan produktivitas bilirubin yang tinggi (tidak ada hemolisis berlebihan) maupun inflamasi hepar (enzim fungsi hati dalam batas normal). Tingginya kadar UCB tersebut mungkin dapat dihubungkan dengan keadaan yang dikenal sebagai Gilbert's Syndrome, yaitu terjadinya mutasi/polimorfisme gen UGT1A1 yang mengekspresikan enzim glucuronosyl transferase. Mutasi/polimorfisme tertentu, baik pada promotor gen ini (perulangan TA, UGT1A1*28) maupun coding region (misalnya pada $211 \mathrm{G}>\mathrm{A}, 247 \mathrm{~T}>\mathrm{C}$ ), menyebabkan ekspresi enzim tersebut menjadi rendah sehingga konyugasi UCB menjadi CB terganggu. Enzim ini juga ternyata dapat menurun aktivitasnya dalam keadaan stress psikologis, termasuk kondisi hipertiroid. ${ }^{7,9}$ 
Gunn rat, jenis tikus mutan yang gen pengode enzim glukoronil transferasenya diknock out, memperlihatkan gejala yang diasosiasikan dengan skizofrenia pada behavioral test seperti open field test dan pre-pulse inhibition test. Pemeriksaan imunohistokimia pada daerah hipokampus otak tikus tersebut menunjukkan banyak mikroglia yang teraktivasi. $^{10}$

Hiperaktivitas dopamin merupakan salah satu etiologi gangguan psikotik/skizofrenia yang lazim diakui. Bahkan pengobatan skizofrenia hingga saat ini masih berfokus pada efek antagonis/blokade reseptor dopamin. Meskipun demikian, penelitian-penelitian terkini juga memperlihatkan keterlibatan neurotransmitter lainnya seperti serotonin (5HT), glutamat, dan lain-lain. ${ }^{11}$ Bilirubin secara esensial menunjukkan efek inhibitor pada proses reuptake dopamin dan glutamat melalui perubahan gradient proton dan potensial membrane. Keadaan ini tentunya dapat mengakibatkan peningkatan kadar dopamin dan glutamat di celah sinaps. Penelitian tersebut mengindikasikan dugaan adanya interaksi inhibitorik antara bilirubin dengan beberapa protein transpor di membran vesikel sinaps yang mungkin dapat menyebabkan hiperaktivitas neurotransmitter lainnya. ${ }^{12}$ Pada rat brain, bilirubin menghambat uptake dopamine dan 5HT pada sinaptosom striatal dan hipokampus. ${ }^{13}$

Dasar imunologis patofisiologi skizofrenia dihubungkan dengan neuroinflamasi akibat aktivasi mikroglia yang pada gilirannya memproduksi peningkatan sitokin-sitokin proinflamasi ${ }^{2}$. Pada astrosit (kultur), UCB terbukti menginduksi peningkatan produksi TNFR1 (reseptor TNF $\alpha$ ), mitogen-activated protein kinase (MAPK), dan nuclear factor $\kappa B$ $(\mathrm{NF}-\mathrm{kB})$. Peningkatan signal efektor tersebut memicu upregulation sehingga sekresi $\mathrm{TNF} \alpha$, IL
$1 \beta$, IL6 juga meningkat. Keadaan ini terbukti menginduksi kematian sel. ${ }^{14}$ Kondisi degenerasi neuron, neurotoksik, penurunan neurogenesis, abnormalitas white matter otak, maupun kematian neuron menjadi salah satu hipotesis etiologi skizofrenia. ${ }^{2}$

Stres psikologis dapat menyebabkan peningkatan radikal bebas ataupun ROS yang ikut mengoksidasi bilirubin menjadi bilirubin oxidative metabolite (BOM). Selain itu, monoamine juga akan dioksidasi oleh monoamine oksidase menjadi metabolit inaktif dengan produk samping berupa oksigen radikal. Peningkatan BOM yang dideteksi di urin ternyata menunjukkan hasil lebih tinggi pada orang yang terekspose dengan stres dan konsentrasinya berhubungan dengan tingkat stresnya (self-rating stress score). ${ }^{15}$ Pada penelitian lain telah dilaporkan bahwa ekskresi metabolit bilirubin (biopyrrin) di urin pada penderita skizofrenia ternyata menunjukkan kadar yang secara signifikan lebih tinggi dibandingkan dengan kontrol, utamanya pada keadaan akut. Kadar biopyrrin cenderung menurun setelah fase akut. Dibandingkan dengan kontrol, kadar biopyrrin urin tetap lebih tinggi pada skizofrenia meskipun dalam sub-acute state (1 bulan setelah terapi) dan remission state. Selain itu, konsentrasi biopyrrin dilaporkan berhubungan dengan skor BPRS pada skizofrenia dan HDRS pada depresi. ${ }^{16}$

\section{Kesimpulan}

Kadar unconjugated bilirubin ditemukan lebih tinggi pada gangguan psikotik, khususnya kelompok skizofrenia. Penelitian lebih lanjut dibutuhkan untuk membuktikan peningkatan UCB ini berkaitan dengan Gilbert's Syndrome via analisis polimorfisme gen UGT1A1, mengelaborasi lebih lanjut efek inflamasi dan konsekuensi gejala klinis pada peningkatan UCB. 


\section{DAFTAR PUSTAKA}

1. www.depkes.go.id

2. Akira Monji et al. Neuroinflammation in Schizophrenia Especially Focused on the Role of Microglia. Neuropsychopharmacol Biol Psychiatry. 2011

3. Karanikas EP, Psyco-immunological mechanism in schizophrenia. 2011

4. Miyaoka T. Schizophrenia and Idiopathic Unconjugated Hyperbilirubinemia (Gilbert's Syndrome). Seishin Shinkeigaku Zasshi. 2011; 113(4): 361-7

5. D.R. Bach, J. Kindler, W.K. Strik. Elevated Bilirubin in Acute and Transient Psychotic Disorder. Pharmacopsychiatry (2010) 43, 12 16

6. Pedoman Penggolongan Diagnostik Gangguan Jiwa (PPDGJ) III

7. Johan Fevery. Bilirubin in Clinical Practice: A Review. Liver International (2008). Blackwell Munksgaard. 592-605

8. Semnani, Yousef, et al. Alteration of serum bilirubin level in schizophrenia. International Journal of Psychiatry in Clinical Practice. 2010 Nov; 14(4): 262-7

9. I Azlin et al. Prevalence of UGT1A1 mutations in Malay neonates with severe jaundice. Malaysian J. Pathol. 2011; 33(2): 95-100

10. Liaury, K, et al. 2012. Morphological features of microglial cells in the hippocampal dentate gyrus of Gunn rat: a possible schizophrenia animal model. J. of Neuroinflammation, 9:56.

11. Kaplan and Saddock's. 2007. Synopsis of Psychiatry: Behavioral Science/Clinical Psychiatry, $10^{\text {th }}$ ed. Lippincott Williams \& Wilkins

12. Roseth S, Hansen TW, Fonnum F, Walaas SI. Bilirubin inhibits transport of neurotransmitters in synaptic vesicles. Pediatr Res. 1998 Sep; 44(3): 312-6

13. Thor W J Hansen, Trine Tydal, Hugo Jorgensen, Dag Bratlid and William J Cashore. The effect of bilirubin on the uptake of 5-ht and dopamine in rat brain synaptosomes. Pediatric Research (1985) 19, 390A-390A

14. Adelaide Fernandes, Ana S. Falca o, Rui F. M. Silva, Ana C. Gordo, Maria J. Gama, Maria A. Brito and Dora Brites. Inflammatory signalling pathways involved in astroglial activation by unconjugated bilirubin. Journal of Neurochemistry. 2006; 96, 1667-1679

15. Yamaguchi T, Shioji I, Sugimoto A, Yamaoka M. Psychological stress increases bilirubin metabolites in human urine. Biochem Biophys Res Commun. 2002 Apr 26; 293(1): 517-20

16. Miyaoka T, et al. Urinary excretion of biopyrrins, oxidative metabolites of bilirubin, increases in patients with psychiatric disorders. Eur Neuropsychopharmacol. 2005 May; 15(3): 249-52. Epub 2005 Jan 25 